\title{
The Soul in Ibn Kammūna's Kalimāt Wajīza
}

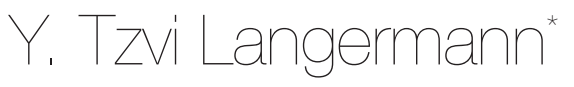

\begin{abstract}
Ibn Kammūna, a late thirteenth-century Jewish philosopher, had a special interest, bordering on an obsession, in the human soul, especially as regards its eternal endurance. One-quarter of his short ethical-philosophical treatise, the Kalimät wajiza, is given over to ilm al-nafs. In this paper, I present an annotated translation of the second of the five chapters that make up that section of the treatise.
\end{abstract}

Keywords: Ibn Kammūna; Ibn Sīnā; soul; îlm al-nafs. 


\section{Part One: Introduction}

Sa'd bin Manșūr Ibn Kammūna (d. 1284) was a Jewish religious thinker and philosopher who spent most of his life in the vicinity of Baghdad. ${ }^{1}$ In common with most other thinkers of his age, his writings exhibit the imprint of Ibn Sīnā. Like Ibn Sīnā (though, as it seems to me, more intensely and probably for different reasons), Ibn Kammūna was greatly concerned with the human soul, especially its afterlife. And again like Ibn Sinā, he took self-awareness to be the surest item of knowledge available, as well as the starting point for acquiring additional knowledge. But by no means is Ibn Kammūna's opus a mere calque upon the work of his illustrious predecessor, for he drank deeply from many sources untouched by Ibn Sīnā: Jewish writings, especially Moses Maimonides and Judah Halevi; Christian writings; and texts by Fakhr al-Din al-Rāzī, an important critic of Ibn Sīnā. Moshe Perlmann demonstrated that Ibn Kammūna utilized all of these, and more, for his inquiry into the three monotheistic faiths. ${ }^{2}$ Moreover, Ibn Kammuna was the first exponent of the Ishrāqi (Illuminationist) school founded, so to speak, by Shihāb al-Dīn al-Suhrawardi, which was offered as an alternative to Avicennan philosophy even if, as is so often the case, it owes a tremendous debt to the school that it criticized. ${ }^{3}$ But he was also in touch with Nașīr al-Dīn al-Ṭūsì, one of the leading intellectuals of his age, and a staunch defender of Ibn Sīnā. ${ }^{4}$

Finally, one cannot emphasize enough that Ibn Kammūna, like most or all thinkers worthy of our consideration, was not merely a pastiche of various "influences". True, some of his writings are composed of near-citations or paraphrases of the writings of others. ${ }^{5}$ Nevertheless, within the Avicennan tradition, he often

1 For a biography and annotated catalogue of his writings, see R. Pourjavady \& S. Schmidtke, A Jewish Philosopher of Baghdad, Leiden-Boston 2006; on the possibility that Ibn Kammūna spent time in Aleppo (Halab) as well, and the significance of this fact for his intellectual biography, see Y. T. Langermann, "Ibn Kammūna at Aleppo," in Journal of the Royal Asiatic Society, third series, 17 (2007), 1-19.

2 M. Perlman, Ibn Kammūna's Examination of the Three Faiths, Berkeley 1971, 1-5. Ibn Kammūna's engagement with Islamic theology is further demonstrated by the commentary published in Critical Remarks by Najm al-Dīn al-Kätibì on the Kitāb al-Ma'ālim by Fakhr al-Dīn al-Rāzī, together with the Commentaries by 'Izz al-Dawla Ibn Kammūna, ed. S. Schmidtke and R. Pourjavady, Tehran 2007.

3 Note, however, that al-Talwīhāt, the text commented upon by Ibn Kammūna, is the most "Aristotlelian" of Suhrawardì's major writings; see now J. Lameer, "Ibn Kammūna's Commentary on Suhrawardì's Talwīhăt. Three Editions, in: Journal of Islamic Manuscripts," 3 (2012), 154-184, for the place of Ibn Kammuna within this tradition and a detailed review of manuscripts and editions.

4 The correspondence between the two is discussed and published by Pourjavady and Schmidtke, $A$ Jewish Philosopher, 118-121, 209-220.

5 See in particular the painstaking analysis of H. Eichner, "The Chapter 'On Existence and Non-existence' of Ibn Kammūna's al-Jadìd fíl-hikma: Trends and Sources in an Author's Shaping the Exegetical Tradition of al-Suhrawardì's Ontology," in Avicenna and his Legacy. A Golden Age of Science and Philosophy, ed. Y. T. Langermann, Turnhout 2009, 143-177. 
exhibits a critical, independent approach. Most significantly for the topic of this paper, he broke with Ibn Sinna on the question of the soul's pre-existence, for he he considered this doctrine critical for his conception of the soul's indestructibility. Lukas Muhlethaler has shown how Ibn Kammūna refines Ibn Sīnās famous "flying man argument". ${ }^{6}$ In general, for all of his large debt to Ibn Sīnā, Ibn Kammūna's writings exhibit his study of a diverse body of extra-Avicennan religious and philosophical literature as well as a certain measure of originality and critical insight.

Ibn Kammūna's literary output has been thoroughly investigated by Pourjavady and Schimdtke, whose study includes not just biobibliographical information, but also critical editions of hitherto unpublished texts. The most important of these are two ethical-religious treatises, a field in which Ibn Kammūna was not known previously to have been particularly interested. The present paper focuses on the longer of the two, the Kalimät wajīza mushtamila 'alā nukat lațîfa fi al-ílm wa-l-'amal (Brief Words covering some subtle witticisms concerning knowledge and practice). This tract was written on the order of Shams al-Dīn al-Qazwīnī, presumably someone well connected at the Mongol court, on behalf of Bahä' al-Dīn al-Juwaynī, governor of Isfahan and its environs. The contents of this interesting tract have yet to receive any serious attention. ${ }^{7}$ The fourth and final section does contain some advice on how to govern, much in line with the so-called genre of "mirrors for princes". However, the bulk of the tract adheres closely to Ibn Kammunna's metaphysics and psychology, with an addition of a great deal of ethics, drawn largely from al-Ghazālī.

The Kalimāt wajizza is divided equally between knowledge ('ilm) and practice ('amal). This pairing is very common in Islamicate ethics, including, but by no means limited to, Sufism. Ibn Kammüna's treatise gives equal space to both, placing knowledge first, in line with the philosophers' view that meaningful practice must be grounded in knowledge. Part 1 has two sections. The first one discusses the deity, referred to here as mudabbir al-álam (governor of the cosmos, cosmocrator), one of labels preferred by the philosophers, and the other section treats of the human soul. Part 2 also has two sections, one concerned with the individual's ethical obligations toward himself and the other with his relations with others. Each of the four sections is divided into five relatively brief chapters; this symmetry in literary structure is characteristic of Ibn Kammūna.

6 L. Muehlethaler, "Ibn Kammūna (D. 683/1284) on the Argument of the Flying man in Avicenna's Ishārāt and al-Suhrawardì's Talwīhāt," in Langermann, op. cit., 179-203.

7 To date, one can point only to a few scattered remarks in the book by Pourjavady and Schmidtke, and several paragraphs in my own entry on Ibn Kammūna in the Stanford Encyclopedia of Philosophy: $<<$ http://plato.stanford.edu/entries/ibn-Kammūna/ >> 
An outstanding feature and defining characteristic of the Kalimāt wajīza is a very sophisticated and sincere Abrahamic philosophical pietism that lies at its heart and directs Ibn Kammūna's presentation of the sundry topics that he takes up in the course of his exposition. "Abrahamic" is, of course, an anachronism. What I have in mind is the fact that Ibn Kammūna, both skilfully and deliberately, wrote a treatise that would seem totally Islamic to his patron but at the same time would be equally appealing to a philosophically inclined Christian or Jew. It is a variant of the type of philosophical piety expressed by thinkers in Antiquity and in medieval Islam, one that has been ably described in a number of academic publications. ${ }^{8}$

I choose nonetheless to call it "Abrahamic philosophical piety", because Ibn Kammūna combines philosophy with significant and unmistakable references to a religious approach to life, specifically to the Abrahamic traditions, but shows no bias toward any one tradition. Here are some examples of how this has been done. To begin with, the reader is identified (using the third person, as is the customary address in treatises of this sort) by non-denominational terms that refer to his quest for guidance: mustarshid (he who takes proper guidance), mustarfid (he who looks for support), or Țālib al-najāt wa-l-kamāl (he who seeks salvation and perfection). Similarly, Ibn Kammūna employs philosophical connotations of the deity, such as al-awwal (the First) or al-wäjib (the Necessary), rather than Allāh (a divine name acceptable to Jews and Christians as well as Muslims), which is used only once or twice. Ethical injunctions are formulated in such a way that each individual may interpret them in line with his own tradition, for example: "Don't allow any food or drink that is forbidden to you to enter your belly". The rare citations fit all of the Abrahamic scriptures: "He is the First and the Last, the Apparent and the Hidden" (Qur'an 57:3; cf. Isaiah 48:12, Revelation 1:8), or "Fear of God is the Beginning of Wisdom" (Psalms 111:10; a "weak" Islamic hadith).

In preparation for his Inquiry, Ibn Kammūna closely studied the literature held sacred by all three Abrahamic faiths, and so we may conclude that his selection of these particular passages was quite deliberate. Finally and most tellingly, a number of explicit statements claim that a broad consensus exists among the traditional Albany 2011; and the comments of N. al-Bizri. B. Mou, and S. Pessin and Azadpur's response in Comparative Philosophy, 3.2 (2012). Azadpur acknowledges his debt to the seminal book of P. Hadot, Philosophy as a Way of Life, Oxford 1995. Should anyone think that Azadpur is hearkening back to the notion of a perennial philosophy, s/he is correct! In his response to al-Bizri Azadpur states, "In other words, my stance has been, to put it polemically, that philosophy is perennial." I heartily endorse Azadpur's position, and reject the claim to the contrary, which argues that all philosophical positions are socially determined. 
religions and the philosophers concerning fundamental beliefs, notably this passage found near the beginning: "The masters of traditional religions (al-diyannat al-naqliyya) as well [the masters] of intellectual tenets (al-'aqā'id al-'aqliyya) agree that salvation and eternal felicity depend upon belief in God, the end of days, and doing good works."

At the time of writing - Pourjavady and Schmidtke fix this date at some time before 1279 - the Mongols had not yet converted to Islam. ${ }^{10}$ Though the rulers at the top were pagans, officials were drawn from other faiths. Many members of the large and powerful Christian minority felt that after half a millennium of subjugation, they had finally freed themselves from the Muslim yoke; for their part, however, the Muslim majority was unused to being ruled by others and did not like it one bit. ${ }^{11}$ Jews also were able to obtain positions of influence at the court. Mob violence was not uncommon; Ibn Kammūna himself was victimized by an angry mob in 1284 that was infuriated by his Inquiry. ${ }^{12}$

It is with this in mind that we must look at his striking piece of advice to the Muslim official in the final section of Kalimāt wajizza:

In giving out what is due, he should not give preference to the high-ranking over the low-ranking, nor to the powerful over the weak, nor to the elect over the commoner, nor to the Muslim over the dhimmin; he must rather pay more attention to the one who behaves arrogantly. Should he see the commoners behaving fanatically towards a [certain] group, aiming to harm them on account of a school of thought [or "doctrine" or even "ideology"; Arabic madhhab], religion, or their following an individual or party, then he should side with the weaker group. Then the powerful

9 Pourjavady and Schmidtke, A Jewish Philosopher, 142. All translations are my own from the Arabic. A nearly identical statement is found in the preface to al-Jadìd fi al-hikma.

10 Ibid., 95-96.

11 Recent scholarship indicates that it is Armenian sources that convey the sense of Christian collusion with the Mongols; the Syriac sources, which reflect the outlook of Christians actually living under Mongol rule, show Christians to have continued to exercise the caution one would expect of a religious minority. See David Bundy, "The Syriac and Armenian Christian Responses to the Islamification of the Mongols," in Medieval Christian Perceptions of Islam: A Book of Essays, ed. John Victor Tolan (New York: Garland Publications, 1996), 33-55; I thank Salam Rassi for this reference.

12 Much has been written on the religious policies of the Mongols; I believe that the remarks I have made in this paragraph lie well within the current consensus. For further reading, see P. Jackson, "The Mongols and the Faith of the Conquered," in Mongols, Turks, and Others: Eurasian Nomads and the Sedentary World, edd. R. Amitai and M. Biran, Leiden-Boston 2005, 245-278; C. P. Atwood, "Validation by Holiness or Sovereignty: Religious Toleration as Political Theology in the Mongol World Empire of the Thirteenth Century," in International History Review 26 (2010), 237-256; and, for a broader perspective, A. M. Khazanov, "Muhammad and Jenghiz Khan Compared: The Religious Factor in World Empire Building, Comparative Studies in Society and History 3 (1993), 461-479. On the episode from Ibn Kammūna's own life, see Pourjavady and Schmidtke, A Jewish Philosopher, 16-17. 
will not be able to seize control over them, nor to harm them in any way. Putting an end to the desire of the commoners [the rabble] to take over is mandatory! ${ }^{13}$

Just what his motivation may have been in preparing a treatise of this nature is, of course, a matter of speculation. Given the shifting fortunes of the different religious communities at the time, one could well argue that his stance in the Kalimät wajizza was dictated by political expediency. I nonetheless favour the view that he is making a sincere statement about the shared values and objectives held in common by all monotheists - those, that is, who share as well a commitment to philosophy. The clearly pro-Jewish bias of his Inquiry notwithstanding, my feeling is that Ibn Kammūna sincerely believed that there was a common ground shared by all philosophically minded monotheists, and that this ground was firm and extensive.

The present paper examines the place of the soul within Ibn Kammūna's Kalimàt wajizza, which is indeed a very important one. Half of the section dealing with knowledge, or one-quarter of the book, is given over to the soul. Ibn Kammūna states that this section has the following five goals: "To establish a group of features ( $a h w w \bar{a} l)$ of the immaterial soul, especially what pertains to the precise determination of her being free [of matter], her transposition after death, the impossibility of her non-existence, and the mode of her felicity and perfection."14

The five chapters cover these topics in order. The first chapter scores two important points: the correct conception of the soul, and the exclusive control exercised by the soul - or, if one chooses to speak in this manner, the "chief soul" - over the body and its actions. The soul is defined as the subject or referent of a statement made in the first person. Whenever I say that "I" did something, the "I" refers to my soul. ${ }^{15}$ One single soul has control over the entire range of bodily faculties and also receives all of the information necessary to decide what to do. Two sorts of input or perception (idrāk) are specified: information conveyed means of the bodily organs and those directions that are not transmitted in this manner. The latter includes lust, aversion, pleasure, pain, will, ability, and action.

14 Ibid., 151. Though ahwāl is usually translated "states", and this is the common rendering of the term in a treatise on the soul ascribed to Ibn Sīnā (concerning which see D. Gutas, The Making of the Avicennan Tradition, Leiden 1988, 305) the context dictates the translation we present, as, indeed, it would be more apt for the pseudo-Avicennan tract as well.

15 It is well-known by now that the Arabic nafs means "self" as well as "soul"; but it is clear enough, even from the list of topics given in the preceding paragraph, that Ibn Kammūna is using the term here consistently to denote the soul. The role of self-knowledge or self-awareness in Avicenna and postAvicennan philosophy is fundamental and much has been written about it; see Muehlethaler. op. cit., 179-83 and notes. 
The stated purpose of the second chapter is to show that "that the soul is neither a body nor does she inhere within one; that she is simple, with no external complexity; and that she is a self-standing substance." ${ }^{16}$ In fact, Ibn Kammūna spends most his time here refuting a range of incorrect conceptions of the soul. The third chapter, on the impossibility of the soul's ceasing to exist, contains arguments for her indestructibility, an important issue, one, in fact, bordering on obsession, for Ibn Kammūna. Chapter 4 takes up the soul's perfection, and, in particular, how she is able to come into contact with and obtain knowledge from the highest world. Some of her "special properties and effects", or rather, those of some gifted souls, are also explained. Here Ibn Kammūna refers to prophets, Sufis, and others who are born with, or acquire by means of "training", extraordinary psychic powers. The fifth and final chapter discusses pleasure and pain, demonstrating that the intellectual varieties of both are more powerful than the sensual ones.

Generally speaking, the views he espouses in the present treatise do not differ from those he expresses elsewhere. However, the orientation of this treatise is evidently pietistic or religious. In my opinion, this emphasis exacerbates tensions between the metaphysical conception of the soul as an unchanging substance engaged in unending self-awareness and the pietistic outlook, which sees the soul as striving for self-improvement, especially by freeing herself from this-worldly concerns, and which sees self-awareness as momentary blessings to which she must be constantly urged. In fact, I sense this tension already in Ibn Sinnā, who labels the passage in which the "Flying Man" thought experiment is described as a tanbih, what we would call today a "wake-up call", and begins the passage with the command to the reader to irjā' ilā nafsika, "Return to your soul!" ${ }^{17} \mathrm{~A}$ fuller exploration of this must be left, perhaps, to another time.

\section{Part Two: Text and Commentary}

In the second section of this essay, I present a translation of and commentary on the second chapter. ${ }^{18}$ I divide the chapter into a series of numbered passages and place my remarks immediately after each passage, exactly as was done in the

16 See below for commentary on this passage.

17 Ibn Sīnā, Al-Ishārāt wa-l-Tanbīhāt, ed. S. Dunya, Cairo 1992, vol. 2, 343. On the "Flying Man", see Muehlethaler, op. cit, and the literature cited there. Muehlethaler, following earlier scholars (especially M. Marmura), speaks often of the soul's "constant" self-awareness, and there are good textual grounds for this remark. However, it seems to me inconceivable that Ibn Sinnā, in the work wherein he exhibits the Sufi side to his philosophy, would have "forgotten" that self-awareness is something that the adept must constantly strive for, not a state he constantly and naturally enjoys.

18 The Arabic text of this chapter is found in Pourjavady and Schmidtke, A Jewish Philosopher, 153-4. 
medieval commentary tradition. As commentator, my primary task to clarify for myself just what Ibn Kammūna is getting at, what points he wishes to score, and how these cohere with the book's plan. I share the results of this labour with the reader in the hope that she or he may find them of some help. Only afterward do I attempt to locate the sources, possible or probable, that Ibn Kammūna utilized.

In the translation, I use feminine pronouns to refer to the soul (nafs), and masculine forms to refer to the essence or self ( $d h \bar{a} t)$. This is consistent with Arabic grammar and allows us to distinguish between the two entities (which are truly one only when the person is in a state of self-awareness).

\section{Chapter Two}

Heading: That the soul is neither a body, nor does she inhere within one [literally, "within it"]; that she is simple, with no external complexity; and that she is a self-standing substance.

Commentary: I suggest a minor emendation in the heading, reading hălla, inhere (from the root h..1.l., here an adjective) rather than hāla "state" or "condition" (from the root h.w.l., here a noun), even though one would ordinarily expect a noun here. Orthographically, my emendation would mean that the shadda has been omitted in the manuscripts, something that is done quite commonly. This emendation is justified by the discussion within the chapter, where Ibn Kammūna rejects the theory that the soul is an inherence (hulül) within a bodily part. ${ }^{19}$ On the other hand, in the final passage of this chapter hāla appears to be used in the sense of "state". ${ }^{20}$

Passage 1: This human soul is not that perishable structure [i.e., the body], nor is she the temperament [mixture] of the body, nor is she a relative proportion of its elements. Those things are always transmuting and dissolving, even though the human person sees himself to be the same [person] that he has been for many years. $^{21}$

19 On the subtlety of the technical terms derived from the root h.l.1 see further P. Adamson, "Avicenna and his Commentators on Human and Divine Self-Intellection," in The Arabic, Hebrew and Latin Reception of Avicenna's Metaphysics, edd. D. N. Hasse and A. Bertolacci, Berlin/Boston 2012, 97-122, esp. 101.

20 See our commentary to Passage 6 below.

21 Kaukua, 208 and note 43, re Avicenna: "What endures unchanged through the constant variation of my corporeal acts and experiential content is the I in me, the narrow first person that is the agent and subject of them all in one and the same sense." On the stability of the person's identity, see further below. 
Commentary: For the most part, this chapter is dedicated to rejecting several false notions about the soul. Note that Ibn Kammuna does not bring into the discussion Ibn Sinā's (basically Aristotelian) definition of the soul as the first entelechy of the body, although he does so in other writings. Some of these incorrect conceptions derive from philosophical or medical traditions, for example, the idea that the soul is nothing but the temperament of the body. He discussed these elsewhere. ${ }^{22}$ Indeed, many definitions or characterizations of the soul are to be found in the traditions with which Ibn Kammuna was conversant. In the preceding chapter, he notes the copious literature on the soul that is available to the reader elsewhere. But why did he select these particular definitions for refutation in this book? Are they an arbitrary selection, aimed at impressing the reader with the variety of definitions on display in the marketplace of ideas, or did he expect Bahā' al-Dīn to be familiar with the particular conceptions recorded in the Kalimät? Is there a political or ethical subtext here? These questions remain open. ${ }^{23}$

The final remark in this section is intriguing indeed. The notion that our identity is fixed and unchanging over the course of a lifetime is found in the Avicennan tradition as part of the argument for an immaterial soul or self. ${ }^{24}$ Yet pietism of the sort advanced by Ibn Kammūna in our treatise urges some form of transformation

22 Ibn Kammunna wrote a special monograph demonstrating that the soul is not a temperament of the body; see Pourjavady and Schmidtke, A Jewish Philosopher 102. On Avicenna's rejection of the soul as temperament see Kaukua, 47. See further Muehlethaler, loc. cit., 59-64; Ibn Kammūna, Al-Jadìd fi alhikma, ed. H. M. al-Kabīsī, Baghdad 1403/1982, 409-412.

23 Many definitions are recorded succinctly in the doxographical tradition; most important for Arabic literature is pseudo-Plutarch's Placita philosophorum, ed. H. Daiber, Die arabische Uebersetzung der Placita Philosophorum, Saarbruecken 1968. See further J.L. Kraemer, Philosophy in the Renaissance of Islam, Leiden 1986, 255-256. On the deliberations of Ibn Sīnā, see J. McGinnis and D. C. Reisman, Classical Arabic Philosophy: An Anthology of Sources, Indianapolis-Cambridge 2007, 175 ff.; P. Heath, Allegory and Philosophy in Avicenna (Ibn Sinnā), Philadelphia 1992, 54-59; and D. N. Hasse, Avicenna's De Anima in the Latin West, London 2000.

24 For close analysis of key passages, see M. Marmura, "Ghazali and the Proof for an Immaterial Self," in A Straight Path, Studies in Medieval Philosophy and Culture. Essays in Honor of Arthur Hyman, edd. R. Link-Salinger, J. Hackett, M.S. Hyman, R.J. Long, and C.H. Manekin, Wahington 1988, 195-205. Surprisingly, historians of Islamic philosophy have not reviewed the Avicennan tradition in the light of contemporary discussions, especially the seminal paper of Denis Parfit, "Personal identity," The Philosophical Review (1971), 3-27. There is a good deal of discussion among students (and practitioners of Buddhism), ostensibly because Parfit himself declared a resemblance between his denial of the self and Buddhism (later partially retracted). I have benefited greatly from Roy W. Perrett, "Personal identity, minimalism, and Madhyamaka," Philosophy East and West 52 (2002), 373-385. The only study I know to engage Parfit (and other contemporaries) from a Jewish perspective is Yitchak Blau "Body And Soul: Tehiyyat ha-Metim and Gilgulim in Medieval and Modern Philosophy," The Torah U-Madda Journal (2001), 1-19. Though Blau's paper reads to me as a mild apology for views on the transmigration of souls accepted by many Jews, the philosophical discussion is balanced. For whatever reasons, Kaukua makes no reference at all to Parfit. 
of the personality, especially in terms of the individual who regards himself as belonging to the material world into one who recognizes his true affiliation with a different, transcendent reality. This transformed identity ought to shine particularly during the moments of self-awareness, which are the moments when the person is truly himself.

So what is stable in the identity of the human individual? That it is not the body or any part of the body is explicit in the text before us. It would not seem to be character traits (which some contemporary consider to constitute the basis of human identity), though Ibn Kammūna avers that some of "configurations" can be transferred to a new instantiation - not that he is ready commit himself to metensomatosis as anything more than a theoretical possibility. Memory would seem to be the best candidate from his perspective; however, in this work he says nothing at all about it.

Passage 2: She is not this totality [or: composite; Arabic jumla, i.e., the human body in its entirety], nor also a particular organ or particular organs, which do not disintegrate in the course of a lifetime, since there is no part of the body whose state the human person does not ignore in the course of some state of self-perception. How can the same thing be perceived and not perceived while in the same state?

Commentary: The idea that the soul is to be identified with the body is found in kalām, or Islamic speculative theology. ${ }^{25}$ Ibn Kammūna's exposition of the second notion, namely, that the soul is not located within any bodily organ, is cumbersome, given that it employs several double negatives. It would be useful to begin by reformulating the argument here in simple language. Were the soul located in a particular part of the body, say in one bone, then, at every instance of self-perception over the course of a lifetime, a person would, in each instance of self-perception, be aware of that bone. But evidently this is not the case. Hence, no particular part of the body is the soul.

The notion that the soul is located in one particular organ of the body, especially one (or all) of the three chief organs (brain, heart, liver), was well-known in Antiquity and repeated in medieval doxographies. Moving closer to Ibn Kammūna's time and place, we note that both Suhrawardī and Fakhr al-Dīn al-Rāzì, two thinkers whose writings (at least some of them) Ibn Kammūna studied closely, ad-

25 The notion that the soul, more precisely the human being, is identical with his body, is held by the Ash'arī school of kalam. See now A. Shihadeh, "Classical Ash'arī Anthropology: Body, Life, and Spirit," The Muslim World 102 (2012), 432-477, at 438. 
vance arguments that the soul cannot be in any particular organ. ${ }^{26}$ In his al-Jadid fi al-hikma (New Wisdom), Ibn Kammūna argues, much as he does here, that the soul cannot be in the heart or the brain, since at any given instance of self-awareness a person will not be aware of one of those organs. ${ }^{27}$ In the text before us, however, he adds that the organ that supposedly houses the soul, or is identical with her, is indestructible; literally, "disintegration (takhalkhul) does not make its way to it". Moreover, in my reading (see below) he defers his rejection of the view that the soul is found in either the heart or the brain to a later passage, where he will offer a different refutation.

I suggest, then, that he is referring here to a tradition found in both Jewish and Muslim sources that the spinal column contains a bone, called in Hebrew luz and in Arabic 'ajb al-dhanab, that is generally identified with the coccyx or os sacrum, which is indestructible and from which the body will be rebuilt at the resurrection. ${ }^{28} \mathrm{Ibn}$ Kammunna's choice of a vertebrum, rather than one of the noble organs recognized by the medieval medical tradition, is in line with the noticeable religious turn of the Kalimāt. Religious traditions, especially those that are common to two or more faiths, are given a stronger voice here than in his other writings.

Passage 3: You already know that whenever he perceives his essence, his perception of himself adds nothing to his essence; and whenever he is like this [in the state of self-perception], his essence exists so long as he perceives it. This entails that whenever the human is not paying attention to its essence while in a certain state [i.e., the human is not self-aware], then he is dissimilar to his essence and not within it, whether it be a body or bodily or neither body nor bodily.

Commentary: I have translated the Arabic dhät as "essence" in order to distinguish it from nafs; it can also be rendered "self". Ibn Kammūna insists that by all

26 R.D. Marcotte, "Irjā ilā Nafsi-ka, Suhrawardī's apperception of the self in light of Avicenna," Transcendent Philosophy 1 (2004), 1-22, at 4-5. Fakhr al-Dīn offers a proof in his al-Mabāhith al-Mashriqiyya, Beirut 1990, vol. II, 375: "Were the intellective faculty inscribed in a body, for example the heart or the brain, then one would always intellectize that body, or one would never intellectize, it, or one would intellectize at some times but not at others. [All] three options [literally: divisions] are false..." Fakhr al-Din's intellective faculty is equivalent to the soul spoken of here by Ibn Kammūna. Indeed, Ibn Kammūna holds that "soul" is called soul only when bound to a body; when free of such an association, it is an intellect (L. Muehlethaler, "Revising Avicenna's Ontology of the Soul: Ibn Kammūna on the Soul's Eternity a Parte Ante," The Muslim World 102 (2012), 597-616, at 614).

27 Ibn Kammūna, op. cit., 413.

28 I find little scholarly literature on this topic; one recommended study is L.N.B. Chipman, "Mythic Aspects of the Process of Adam's Creation in Judaism and Islam,” Studia Islamica 93 (2001), 5-25, at 23. Another possibility is the idea broached by al-Ghazāli, that the original sperm remains in the body throughout one's life; see Marmura, op. cit., 200. 
accounts, even should one adhere to one of the theories that the soul is a body or a bodily faculty, a person is not really oneself in the absence of self-awareness. This is in no way a retreat from his belief that the soul is immaterial, but rather another indication that in this treatise the ethical-religious message takes precedence over scientific precision. The demand for self-awareness, to the extent that we are "really" ourselves only when self-aware, was a strong element in the piety of his period. Sufis and others railed against ghafla, "lack of awareness", "dormancy", or, as we translated in the text above, "not paying attention to". ${ }^{29}$ In the Kalimät the ethical imperative to be aware of oneself takes precedence over the philosophical teaching about the nature of the soul. Marcotte observes that according to Suhrawardi, the soul can never be unaware of itself. ${ }^{30}$ Ibn Kammūna would agree that we "really" are, that is, we truly exist, only when we are self-aware.

In the opening section of the Kalimàt, Ibn Kammūna builds his first proof that there is only one deity, or cosmocrator, from the facts of human self-awareness:

His [God's] unicity is proven by [the fact that] the human, when he perceives his [own] self (dhāt) and points to it [gestures mentally towards his own self] will find in his self only something that perceives itself. Everything else is unknown, be it real or unreal [something that exists or something whose existence is denied]: it is exterior to his self. He does not perceive his self by means of a form that is added to his self [i.e., the percept is not a "form" added to the self; it is rather the very self]. Indeed, every form that is added onto the self is indicated from its [the self's] direction; and it [the self] indicates its own self by means of "I". Its perception cannot be dissevered from its self. ${ }^{31}$

The full proof is less interesting. It is a rather standard rejection of dualism: If the two self-perceiving deities differ in their self-perception, then the one perceiving the more noble self is god; if they are entirely equal in what they perceive in themselves, then they are two members of a species and thus there must be some external factors differentiating between them. Far more striking is the parallelism between human and divine self-awareness that Ibn Kammūna draws in the passage just cited, beginning with the more certain of these, namely, human self-awareness.

29 To give just one example, surely known Ibn Kammūna, Maimonides speaks of ghafla at the end of the tenth chapter of the second part of his Guide of the Perplexed.

30 Marcotte, op. cit., 4, with specific reference to hikmat al-Ishrāq, Suhrawardì's major statement of his philosophy.

31 Pourjavady and Schmidtke, 148. This passage must be considered along with Ibn Kammūna's other statements on self-awareness, which, as Muehlethaler has shown ("Flying Man", but without reference to the Kalimät), differ. P. Adamson, "Human and Divine Self-Intellection," amasses a great deal of relevant material, but I do not find there any argument similar to that put forward here by Ibn Kammūna. 
In the second section of the Kalimāt wajiza, which deals with praxis, Ibn Kammūna remarks that "the spirit bears some relationship to the divine thing". That section is taken over, in part literally, from al-Ghazāii. He carries over the latter's term, rūh (spirit), even though it plays no role in his own psychology. ${ }^{32}$ Nonetheless, it is clear that a quasi-divine status, be it ascribed to soul or spirit, is paramount in Ibn Kammūna's worldview.

Passage 4: We have already seen that everything that knows its [own] essence is simple, with no internal complexity lying outside the mind. Rather, should it be thought to contain some complexity, it would [only] be in light of (bihasbi) mental reflection, not external reality. The human soul must be like this.

Commentary: Ibn Kammūna states that the soul is "simple" and that this is something "that we have already seen". No proof for this particular claim has been given in his Kalimät wajīza, but one is presented in Ibn Kammūna's shorter ethical treatise, the Risāla fi Ithbāt al-Mabda'. ${ }^{33}$ It is, in fact, the same proof given in part 1, chapter 3 of the Kalimāt for the simplicity of the "Necessary Existent". The proof (for the soul) runs as follows: Knowledge of the part precedes knowledge of the whole. So whatever knows its own essence knows it first from its part. Now whoever knows something also knows that he knows it; this rule applies as well to knowledge of one's own essence. Were the soul complex, this would entail the impossible conclusion that she knows her own essence before she knows a part of her essence, which partial knowledge must be secured before she can know her own essence (as a whole). The only way out of this quandary is to assert that the soul has no parts. Instead, she is simple and her self-knowledge is the knowledge of her own essence.

Ibn Sinnā had also maintained that the soul is simple; however, he presents no proof and, as Peter Adamson has shown, is not totally consistent on this point. ${ }^{34}$

32 See Pourjavady and Schmidtke, op. cit., 167, and compare al-Ghazālī's al-Arba în fì Ușūl al-Dīn, ed. 'A.'A. 'Urwānī and M.B. al-Shaqfa, Damascus: Dar al-qalam, 1424/2003, 144; The same ideas are expounded at much greater length in al-Ghazālī's Ihyyā 'Ulūm al-Dīn, Kitab dhimm al-Jāh wa-l-Riyā' (Book 8 of rub' al-muhlikāt), III, 257 ff. Al- Ghazālī uses rūh because his claim that the spirit has something divine ('amr ilāhì) is a play on words on the Qur'anic verse (17:85) which he cites. Ibn Kammūna leaves out the Qur'anic citation--I suggest that he does so, not just for the sake of brevity, but in keeping with his effort to keep the Kalimāt religiously neutral. Nonetheless, the terminological aberrance does not bother him.

33 Pourjavady and Schmidtke, op. cit., 187. Once again, the translation is my own. My translation and analysis of this tract will appear in the Writing in Light: Illuminationist Texts and Textual Studies in Honor of the Late Hossein Ziai, edited by John Walbridge, Ali Gheissari, Ahmed Alwishah. Elsewhere Ibn Kammūna uses the proposition that the soul is simple to prove her eternity a parte ante; see Muehlethaler, Revising Avicenna's Ontology, 610.

34 P. Adamson, "Non-Discursive Thought in Avicenna's Commentary on the Theology of Aristotle," in 
Indeed, the soul's simplicity is not such a simple matter, and thus Ibn Sinnās position was subjected to much critical discussion by his students and followers. Fakhr al-Dīn al-Rāzì devotes several pages of his al-Mabāhhith al-Mashriqiyya to this question, which he introduces as follows:

This is the proof [for the immateriality of the soul] that the shaykh [Ibn Sinnā] decided upon in his Kitāb al-Mubāhathāt, claiming that this proof is the best one that he has on this subject. But then his students raised many objections against it, to which the shaykh responded. However, the questions and replies are scattered. I have arranged them and display them here in good order. So we say: "We are able to intellectize our essences (dhawātanā). Whoever intellectizes an essence possesses the quiddity (mähiyya) of that essence. Therefore, we possess the quiddity of our essence. Now it must be the case that either we intellectize our essence because another form, identical (musāwiyya, literally "equal") to our essence, arises in (tahsul fi) our essence, or else it is on account of [the fact that] our very essence (nafs dhätina) is present to (hādira li-) our essence. The first [option] is false because it leads to a coalescence (jam) between two similar things; therefore the second [option] is specified [as the correct one]." ${ }^{35}$ Now whatever has its essence present to its essence is self-subsisting. [Note the definition here of the key term, $q \bar{a}$ 'im bi-dhätihi: something that has its own essence within, present to itself]. Therefore, the intellective faculty is self-subsisting ( $\left.q a a^{\prime} i m ~ b i-n a f s i h a\right)$. No body or bodily thing (jismānī) is self-subsisting. Ergo, the intellective faculty is neither a body nor a bodily thing. ${ }^{36}$

It seems that Ibn Kammuna was aware of the difficulties of the claim that the soul is simple - difficulties that, so it appears, apply equally well to the key theological claim that the deity is simple. He concedes that mental reflection, or philosophical analysis, may lead one to think that the soul is complex (as indeed Adamson observes that the very fact of discursive reasoning, employing a complex syllogism, argues for this conclusion), but nonetheless declares that this complexity is solely "in light of mental reflection"; in reality, the soul is simple.

Interpreting Avicenna: Science and Philosophy in Medieval Islam, ed. J. McGinnis, Leiden: Brill, 87-111, at 95. As a way out of the quandary, Ibn Sīnā considered "grades of simplicity" (ibid., n. 20).

35 Is Fakhr al-Din invoking a principle of economy here to justify his rejection of the first option ("a coalescence of similar things")? Compare the argument of Suhrawardi, cited by Marcotte, op. cit., 1011: "because if its knowledge of its essence were by means of an image, the image of the essence's individual being (anāiyya) would be other than itself. In such a case, perception and knowledge of the self would only amount to the perception of the representation of the essence." Cf. ibid, 15, where Marcotte discusses the dream in which Aristotle reveals to Suhrawardi that if the soul required another entity in order to perceive its own essence, this would lead to an infinite regress. A somewhat similar claim is made by Ibn Kammūna in the final section of the paragraph under analysis here.

36 Al-Rāzī, op. cit., vol. 2, 366. The discussion of the various objections to Ibn Sīnā and the replies of the shaykh continues for some six pages. David Reisman, The Making of the Avicennan Tradition: The Transmission, Contents, and Structure of Ibn Sīnä's Al-Mubāhathāt (the Discussions), Leiden-Boston 2002, is replete with biographical and bibliographical data; for a philosophical analysis of the exchanges recorded in al-Mubāḥathāt, see Marcotte, op. cit. 
In the passage that follows, Ibn Kammuna refutes some other conceptions of the soul that were known to him, all of which view the soul as something that inheres or flows through the body. Their rejection comes at this point in the chapter, presumably because they violate the soul's simplicity.

Passage 5: She cannot be a body nor [something] inhering within it [the body, i.e.,] as an inherence, a diffusion (hulūl sarayān); otherwise, she would be divided into parts by the connection. But if she were divided into parts by means of the division into adjacent parts (tajzía ittișāliyya, literally: "connective particularization"), she would not receive the acquired traits (malakāt) that are not divided into parts in that way, such as the traits of knowledge, cleverness, bravery, cowardice, and carelessness; they [the traits just listed] rather have only strengthening and weakening. [If it were] otherwise [should the soul be made of connected parts, then], should these or similar [traits] be received by her, they would be divided according to the divisions of that within which they inhere. They would be divided into parts by division into adjacent parts [again, literally, "connective particularization"; this repetition is characteristic of the Arabic idiom], and that contradicts what has been assumed.

Commentary: Ostensibly, Ibn Kammūna has already dispensed with all of the errant theories that construe the soul as a material or quasi-material entity. Why, then, does he raise the issue again, and why does he do so in the context of acquiring ethical traits? By way of first approximation, I observe that the notion under attack here seems to be that of a soul inhering in several locales within the body, the parts linked together by something that flows throughout the body. This recalls, even if Ibn Kammūna omits the details, the Platonic-Galenic tripartite soul, including as well the pneuma (spirit, rüh) that flows though the body and links together her parts one with the other and with the body as well. ${ }^{37}$ Having said this, we must note that elsewhere, where he tackles the notion of inherence (hulūl), he closely follows the analysis of Abü-l-Barakāt al-Baghdādī. ${ }^{38}$ However, al-Baghdādi does not make the argument from the unicity of the acquired virtues or character traits, as Ibn Kammuna does here. This same argument, namely, that

37 Concerning the problematic nature of the Platonic-Galenic theory for the Avicennan, see R. Hall, Intellect, Body, and Soul in Ibn Sīnā, in: Interpreting Avicenna; Hall observes, "The most important task in synthesizing the opposed Aristotelian and Galenic traditions in psychology is getting away from deeply unsatisfactorily divided soul of Plato, which was adopted by Galen. The Platonic tripartition of the soul/person is almost an assertion of three contending souls within each individual and is disastrous for general theoretical psychology" (ibid., 73 ).

38 L. Muehlethaler, Ibn Kammuna (D. 683/1284) On the Eternity of the Human Soul. The Three Treatises on the Soul and Related Texts, Ph.D. Dissertation, Yale University 2010, 65. 
the virtues do not are not made up of discrete parts that are joined together, is made in the New Wisdom; however, Ibn Kammūna does not mention inherence in that work. ${ }^{39}$ In his monograph on the soul, he produces detailed arguments for her unicity that are based on the indivisibility of knowledge; he does not deal with the other traits. ${ }^{40}$

The added detail, that this inherence is a diffusion or flow (sarayān) through the body, is only made here, as far as I can determine. Let's look more closely at the two terms, seemingly joined together in status constructus, that Ibn Kammuna uses for the first time in this passage: hulūlu sarayānin. The first of these, hulūl, is a loaded term in the Islamic context, as it is used, inter alia, to describe the Christian doctrine of the inherence of the divine in Jesus and also the martyred mystic al-Hallāj's description of his state of union with the divine. ${ }^{41}$ hulūl was also used to describe the soul's inherence or residence within a particular organ, as indeed Ibn Kammūna does in the passage referred to above from his New Wisdom. ${ }^{42}$

Sarayān plays a role in a theory of the soul ascribed to Thābit bin Qurra, the tenth-century Sabian scientist and philosopher. To be more specific, Thābit speaks of the flow of the spirit through the body; the spirit is responsible for the connection (ittiṣāl, the same term used by Ibn Kammūna) between the soul and the body. ${ }^{43}$ The two terms, joined together, are used by Nașīr al-Dīn al-Ṭūsī in his short tract on the soul's survival after death. Al-Ṭūsī first defines ḥulūl and sarayān as two modes of inscribing (irtisām) one thing in another, the former static, like the

39 Ibn Kammūna, Al-Jadìd fì al-ḥikma, ed. H. M. al-Kabīsī, Baghdad 1403/1982, 413.

40 Muehlethaler, Dissertation, $179 \mathrm{ff}$.

41 On the concept of hulūl see L. Massignon and C.G. Anawati, hulūl, in: Encyclopaedia of Islam, Second Edition. Brill Online, 2013. Reference. Bar Ilan University. 09 January 2013 http://referenceworks. brillonline.com/entries/encyclopaedia-of-islam-2/hulul-SIM_2944; further details in Massignon's masterful La Passion d'al-Hosayn-Ibn-Mansour al-Hallaj: martyr mystique de l'Islam, Paris 1922, passim, s.v. holoūl. For a rich survey of the usages of the term in Arabic and Hebrew letters, see D. Lobel, “A Dwelling Place for the Shekhinah," Jewish Quarterly Review 90 (1999), 103-125.

42 A similar argument is found in the writings of a seventeenth century thinker, al-Lāhijī who remains firmly within the medieval tradition: For example, the repudiation of hulül in al-Lāhijīs commentary to al-Ṭūsì's Tajrìd al-Aqẫ'id is part and parcel of the rejection of the soul's corporeality and its location within a single bodily organ, two ideas that have already been rejected: "That the soul does not inhere ('adam hulūl al-nafs) in the body. Were the soul corporeal, she would inhere in one part of the body, either in the heart or the brain. This would entail either her always intellectizing it [that part in which she resides], or her not intellectizing it at all. The second of these is false, since the soul intellectizes [both] the heart and the brain from time to time." Cited from the excellent, annotated edition accessible on line at http://tohid.ir/ar/index/book?bookID=199\&page=1, visited December 2012.

43 I discuss this at length in "Naturalization of Science in Ibn Qayyim al-Ğawziyyah's Kitāb al-Rūh," in A Scholar in the Shadow: Essays in the Legal and Theological Thought of Ibn Qayyim al-Ğawziyyah, Oriente Moderne, N.S., 90 (2010), edd. C. Bori and L. Holtzman. 211-228, at 221-223. 
inscription or inherence of a point in a line, and the second dynamic, such as the flow of a form in a mirror. The contrast between the two is emphasized: "The point does not flow (tasriy) through the length of the line..." ${ }^{44}$ Later, though, when establishing that the soul does not accept division - much the same issue raised by Ibn Kammunna in the passage under discussion - the two are combined: "Every thing that is inscribed in something susceptible to division in the manner of flowing inherence ('alā sabil al-ḥulūl al-sarayāniy) divides according to its division. Every body (jism) accepts positional division. Thus the soul is neither a body, nor [is it] a faculty (qüwa) inhering in the body by a flowing inherence." ${ }^{45}$

The passage cited in the preceding paragraph is very close to the one we are commenting on here. There is, however, a significant difference: In our text, Ibn Kammuna attacks from the angle of moral psychology. In this respect, his critique resonates with earlier discussions of the problematics of the Platonic division of the soul in the ethical sphere. Critiques of this sort are found in the writings of Evagrius of Pontus and Gregory of Nyassa, which have been studied by Kevin Corrigan. Although I can point to no textual links between Ibn Kammūna and these two fourth-century Church fathers, their deliberations are nonetheless very relevant because they grappled with Platonic psychology as part of their commitment to ascetism. Phenomenologically, then, their discussions are relevant to Ibn Kammūna's pietistic treatise, which, if not strictly ascetic, definitely urges the reader away from this-worldly pursuits. For example, Evagrius writes in his Praktikos that the virtues do not merely strengthen or weaken, but actually take on new identities when associated with different parts of the soul: Since the rational soul is tripartite according to our wise teacher, when virtue arises in the rational part it is called prudence, understanding, and wisdom; when it arises in the concuscible part it is called chastity, love, and abstinence; and when it arises in the irascible part it is called courage and perseverance; but when it penetrates the entire soul it is called justice.... ${ }^{46}$ This is precisely the issue that Ibn Kammūna addresses, even if he disagrees with Evagrius: In truth, virtues strengthen or weaken. Were the soul to be found in different parts of the body, the virtues would also be divided and presumably take on new identities in each domicile.

45 Ibid., 47-8.

46 Kevin Corrigan, "The Organization of the Soul: Some Overlooked Aspects of Interpretation from Plato to Late Antiquity," in Reading Ancient texts, Volume II: Aristotle and neoplatonism, edd. S. Stern-Gillet and K. Corrigan, Leiden-Boston 207, 103. Corrigan finds that some of the ideas of these early Christian thinkers trace back to the pseudo-Aristotelian treatise, On Virtues and Vices. See further idem, Evagrius and Gregory: Mind, Soul, and Body in the $4^{\text {th }}$ Century, Farnham and Burlington, 2009, 66-71. 
Passage 6: The soul is not a state [or: condition] within something, be it immaterial or not; otherwise that something would be self-subsisting or it would end up [being traced back to] that which is self-subsisting. Then that would be the thing to which the activities are to be ascribed, insofar as it has some accident within it, rather than [its being ascribed] to that accident [which acts] by means of it. Don't you see that one says, 'The soul acted by [its] ability or by the will'; one does not say, 'The will and ability acted by means of the soul.' This is evident to everyone who can see.

Commentary: This is a difficult passage. There are grammatical issues with the textus receptus (assuming one can rely on the edition, which I do) as well as substantive issues in understanding what Ibn Kammūna's worries are here. I suggest that we work our way backward. The final point, and decisive proof, is that in normal discourse one says that the soul acts by means of the will; one does not say that the will acts by means of the soul. This implies that the theory rejected here claims that the soul is really a state of the will (or ability).

Now let us go back to the opening statement, "The soul is not a state [or: condition] within something, be it immaterial or not". The second part reads in Arabic: siwa ' kānat mujarradan aw ghayra mujarradin. Känat is feminine and must refer back to the soul; but mujarrad is masculine and must refer to the "thing" (shay') in which the soul exists as a state. The following sentence has a masculine subject, which must be the thing (shay'). Hence one ought to correct kānat to the masculine form, kāna; the lack of any manuscript that gives the correct formulation indicates to me that the copyists did not quite follow Ibn Kammūna's reasoning here. ${ }^{47}$ The upshot of this obscure passage would be this: the soul is certainly immaterial, but it may be thought to be a state or condition obtaining in something material (perhaps, again, the heart or the brain) or immaterial (the will or ability, as in the final sentence). Any such notion is to be rejected, because that would make the soul an accident and not a true agent, that is, the entity that is responsible for the person's actions. Instead, it would merely be an instrument of the "thing" in which it inheres, and that is patently false. Its falsity is evident from common human speech; no one says, "My will acted though the instrumentality of my soul". Abū al-Barakāt al-Baghdadī in particular holds that common speech may reflect true conceptions of subtle conceptions of subtle ideas. ${ }^{48}$

47 In note 231 on page 154, Pourjavady and Schmidtke list the variant fa-kānat, which they rightly reject; that would suggest that the subject of the sentence "is immaterial or not" is nafs, "soul", which is clearly wrong.

48 48. This is the case, for example, for the conception of time; see Shlomo Pines, Nouvelles Etudes sur Awhad al-zaman Abu-l-Barakāt Al-Baghdadi.-Memoires de la Societe des Etudes Juives ${ }^{\circ}$ Vol. 1. Durlacher, 1955, 32-33 (reprinted in the Collected Works of Shlomo Pines, vol. 1). 


\section{Bibliography}

Adamson, Peter. "Non-Discursive Thought in Avicenna's Commentary on the Theology of Aristotle." In Interpreting Avicenna: Science and Philosophy in Medieval Islam, ed. J. McGinnis. Leiden: Brill, 2004, 87-111.

"Avicenna and his Commentators on Human and Divine Self-Intellection." In The Arabic, Hebrew and Latin Reception of Avicenna's Metaphysics, ed. D. N. Hasse and A. Bertolacci. Berlin and Boston: De Gruyter, 2012, 97-122.

Atwood, C. P. "Validation by Holiness or Sovereignty: Religious Toleration as Political Theology in the Mongol World Empire of the Thirteenth Century." International History Review 26 (2010): 237-56.

Azadpur, Muhammad. Reason Unbound: On Spiritual Practices in Islamic Peripatetic Philosophy. Albany: SUNY, 2011.

al-Bizri, N., B. Mou, and S. Pessin and M. Azadpur "Response to Azadpur, Reason Unbound." Comparative Philosophy $3.2(2012)$

Blau, Yitchak. "Body And Soul: Tehiyyat ha-Metim and Gilgulim in Medieval and Modern Philosophy." The Torah U-Madda Journal (2001): 1-19.

Corrigan, Kevin. "The Organization of the Soul: Some Overlooked Aspects of Interpretation from Plato to Late Antiquity." In Reading Ancient texts, Volume II: Aristotle and Neoplatonism, ed. S. Stern-Gillet and K. Corrigan. Leiden and Boston: Brill, 2007, 97-114.

Bundy, David. "The Syriac and Armenian Christian Responses to the Islamification of the Mongols." In Medieval Christian Perceptions of Islam: A Book of Essays, ed. John Victor Tolan. New York: Garland Publications, 1996, 33-53.

Chipman, Leigh N. B. “Mythic Aspects of the Process of Adam's Creation in Judaism and Islam." Studia Islamica 93 (2001): 5-25.

Daiber, Hans. Die arabische Uebersetzung der Placita Philosophorum. Doctoral Thesis Saarbruecken, 1968.

Eichner, Heidrun. “The Chapter 'On Existence and Non-existence' of Ibn Kammūna's al-Jadìd fï l-hikma: Trends and Sources in an Author's Shaping the Exegetical Tradition of al-Suhrawardì's Ontology." In Avicenna and His Legacy: A Golden Age of Science and Philosophy, ed. Y. T. Langermann. Turnhout: Brepols, 2009, 143-77.

al-Ghazālī. al-Arbaîn fì Ușūl al-Dīn., Ed. A. A. 'Urwānī and M. B. al-Shaqfa. Damascus: Dār al-Qalam, 1424/2003.

Gutas, Dimitiri. The Making of the Avicennan Tradition. Leiden: Brill, 1988.

Hall, Robert. "Intellect, Body, and Soul in Ibn Sīnā." In Interpreting Avicenna: Critical Essays. Ed. Peter Adamson. Cambridge: Cambridge University Press, 2013, 62-86.

Hadot, Pierre. Philosophy as a Way of Life. Oxford: Oxford University Press, 1995.

Hasse, Dag N. Avicenna's De Anima in the Latin West. London: Warburg Institute, 2000.

Heath, Peter. Allegory and Philosophy in Avicenna (Ibn Sinā). Philadelphia: University of Pennsylvania, 1992, 54-59.

Ibn Kammūna. Al-Jadìd fi al-ḥikma. Ed. H. M. al-Kabīsī. Baghdad: Wizārat al-Awqāf, 1403/1982.

Ibn Sīnā. Al-Ishārāt wa-l-Tanbīhāt. Ed. S. Dunya, Cairo 1992.

Jackson, Peter. "The Mongols and the Faith of the Conquered." In Mongols, Turks, and Others: Eurasian Nomads and the Sedentary World. Ed. R. Amitai and M. Biran, Leiden and Boston: Brill, 2005, 245-78.

Kaukua, Jari. Self-Awareness in Islamic Philosophy. Cambridge: Cambridge University Press, 2014.

Khazanov, A. M. "Muhammad and Jenghiz Khan Compared: The Religious Factor in World Empire Building." Comparative Studies in Society and History 3 (1993), 461-79.

Kraemer, Joel L. Philosophy in the Renaissance of Islam. Leiden: Brill, 1986.

Lameer, Jaap. “Ibn Kammūna's Commentary on Suhrawardī's Talwīhāt. Three Editions. Journal of Islamic Manuscripts, 3 (2012), 154-84.

Langermann, Y. Tzvi. “Ibn Kammūna at Aleppo." Journal of the Royal Asiatic Society, 3d series, 17 (2007), 1-19.

na/.

."Ibn Kammūna," Rhe Stanford Encyclopedia of Philosophy: http://plato.stanford.edu/entries/ibn-Kammū-

"Naturalization of Science in Ibn Qayyim al-Ğawziyyah's Kitāb al-Rūh." A Scholar in the Shadow: Essays in the Legal and Theological Thought of Ibn Qayyim al-Ğawziyyah. Oriente Moderne, N.S., 90 (2010). Ed. C. Bori and L. Holtzman. 211-28. 
--_--_- "IIm, 'amal, and the stability of the self in a short treatise by Ibn Kammūna (d. 1284)," to appear in Günther Mensching and Alia Mensching-Estakhr, ed., Die Seele im Mittelalter. Von der Substanz zum funktionalen System (Würzburg: Königshausen \& Neumann, end of 2016).

Lobel, Diana. “A Dwelling Place for the Shekhinah.” Jewish Quarterly Review 90 (1999): 103-25.

Marcotte, Roxanne D. "Irjā ilā Nafsi-ka, Suhrawardī's apperception of the self in light of Avicenna." Transcendent Philosophy 1 (2004): 1-22.

Marmura, Michael. "Ghazali and the Proof for an Immaterial Self." In A Straight Path: Studies in Medieval Philosophy and Culture. Essays in Honor of Arthur Hyman. Ed. R. Link-Salinger, J. Hackett, M. S. Hyman, R. J. Long, and C. H. Manekin. Washington: Catholic University 1988, 195-205.

Massignon, Louis. La Passion d'al-Hosayn-Ibn-Mansour al-Hallaj: martyr mystique de l'Islam. Paris: P. Geuthner, 1922.

Massignon, Louis, and C. G. Anawati. “ḥulūl," in: Encyclopaedia of Islam, 2d ed. Brill Online, 2013.

McGinnis, Jon and D. C. Reisman. Classical Arabic Philosophy: An Anthology of Sources. Indianapolis and Cambridge: Hackett, 2007.

Muehlethaler, Lukas. “Ibn Kammūna (D. 683/1284) on the Argument of the Flying Man in Avicenna's Ishärāt and al-Suhrawardī's Talwīhăt.” In Tvzi Langermann, Avicenna and his Legacy, 179-203.

Ibn Kammuna (D. 683/1284) On the Eternity of the Human Soul. The Three Treatises on the Soul and Related Texts, Ph.D. Dissertation, Yale University, 2010.

."Revising Avicenna's Ontology of the Soul: Ibn Kammūna on the Soul's Eternity a Parte Ante." The Muslim World 102 (2012): 597-616.

Parfit, Denis. "Personal identity." The Philosophical Review (1971): 3-27

Perlman, Moshe. Ibn Kammūna's Examination of the Three Faiths. Berkeley: University of California, 1971.

Perrett, Roy W. "Personal identity, minimalism, and Madhyamaka." Philosophy East and West 52 (2002): 373-85.

Pines Shlomo, Nouvelles Etudes sur Awhad al-zaman Abu-l-Barakat Al-Baghdadi. Memoires de la Societe des Etudes Juives. Vol. 1. Durlacher, 1955, 32-33 (reprinted in the Collected Works of Shlomo Pines, vol. 1, Jerusalem and Leiden: Magnes-Brill, 1979).

Pourjavady, Reza and S. Schmidtke. A Jewish Philosopher of Baghdad. Leiden and Boston: Brill, 2006

Al-Rāzī, Fakhr al-Dīn. al-Mabāḥith al-Mashriqiyya, ed. M. al-Baghādī, 2 vols. Beirut: Dār al-Turāth al-'Arabī, 1990.

Reisman, David. The Making of the Avicennan Tradition: The Transmission, Contents, and Structure of Ibn Sinä's AlMubāhathāt (the Discussions). Leiden and Boston: Brill, 2002.

Schmidtke, Sabine and R. Pourjavady. Critical Remarks by Najm al-Dīn al-Kātibī on the Kitāb al-Ma'ālim by Fakhr al-Dīn al-Rāzī, together with the Commentaries by 'Izz al-Dawla Ibn Kammūna. Tehran : Iranian Institute of Philosophy; Berlin : Institute of Islamic Studies, Free University of Berlin, 2007.

Shihadeh, Ayman. “Classical Ash'arī Anthropology: Body, Life, and Spirit." The Muslim World 102 (2012), 432-77. 